\title{
Sika ihmisen mallina lihavuustutkimuksessa - pilottikoe
}

\author{
Liisa Voutila $^{1)}$, Kirsi Partanen ${ }^{1)}$, Pertti Marnila ${ }^{2)}$, Susanna Rokka ${ }^{2)}$ ja Raija Tahvonen ${ }^{2)}$
}

${ }^{1)}$ MTT Kotieläintuotannon tutkimus, Tervamäentie 179, 05840 Hyvinkää, liisa.voutila@mtt.fi, kirsi.partanen@mtt.fi

${ }^{2)}$ MTT Biotekniikka- ja elintarviketutkimus, Alimentum, 31600 Jokioinen, pertti.marnila@mtt.fi, susanna.rokka@mtt.fi, raija.tahvonen@mtt.fi

\section{Tiivistelmä}

Tausta. Ihmisten ravitsemustutkimuksessa tutkimusongelman kannalta oleellisten kudosnäytteiden saaminen on yleensä haasteellista eettisistä syistä. Eläinmalleina jyrsijät ovat yleisimpiä, mutta niissä näytteiden käytettävyyttä rajoittaa näytteen koko ja jonkin verran eroavat metaboliat (esim. kolesteroli). Sikaa pidetään aineenvaihdunnaltaan ihmisen kaltaisena ja sioista saatavien näytteiden koko on tutkimuksen näkökulmasta parempi kuin jyrsijämalleissa. Veri- ja kudosnäytteistä voidaan mitata tunnettuja fenotyyppiä kuvaavia markkereita ja samoista näytteistä voidaan määrittää geneettisiä parametreja. Lisäksi näytteistä voidaan määrittää metabolomia ja tarvittaessa myös geenien polymorfiaa. Tämä koe oli pilottikoe usean sukupolven kokeelle, jossa testataan lihavuuden mahdollista periytymistä ja sen estämistä.

Tavoitteet. Tavoitteena oli selvittää, soveltuuko suomenmaatiaissika ihmismalliksi monen sukupolven koetta varten. Kokeessa selvitettiin sikojen painonkehitys, rasvoittuminen ja kiimaantuloaika ihmisravitsemusta muistuttavalla ruokinnalla, jossa energianlähteenä oli tavanomaisten rehuraaka-aineiden lisäksi sokeria, margariinirasvaa ja voita.

Kokeen suoritus. Yhteensä 43 suomenmaatiaisimisää kasvatettiin 135-140 kg elopainoon kaksivaiheisella ruokinnalla. Ruokintaryhmät olivat 1) kontrolli eli tavanomainen ensikkoruokinta, 2) rehussa 8,4\% lisärasvaa ja $15 \%$ sokeria, 3 ) rehussa 14,6\% lisärasvaa ja $15 \%$ sokeria ja 4) rehussa 13,9 \% lisärasvaa, 10 $\%$ sokeria ja $10 \%$ vehnänlesettä kuitulähteeksi. Ryhmissä 2-4 kontrollirehun kilot korvattiin asteittain koerehulla 7 viikon totutusjakson aikana.

Tulokset. Sikojen kasvujen keskiarvot ryhmissä 1, 2, 3 ja 4 koko kokeen aikana olivat 1009, 996, 975 ja $992 \mathrm{~g} / \mathrm{pv}$. Selkäsilavan paksuus teurastamolla mitattuna oli koko aineistossa välillä 14,9-18,2 ja imisien kiimaan tuloikä oli ryhmissä 1-4 149-159 d, mutta erot eivät olleet tilastollisesti merkitseviä. Laskimoveressä ryhmien välisiä eroja oli vain kokeen lopussa, noin 130-140 kg painossa. Tuolloin ryhmän 4 sioilla oli veressä enemmän granulosyyttejä kuin ryhmässä $1\left(7,01 \times 10^{6}\right.$ vs. $5,34 \times 10^{6}$ solua/ml, $\left.\mathrm{P}<0,05\right)$. Kokoveren valkosolujen radikaalien tuotto ("respiratory burst"-vaste opsonisoidulle zymosaanille) oli ryhmän 3 sioilla 2,5 min ja ryhmän 4 eläimillä 3 min nopeampaa kuin ryhmässä $1(\mathrm{P}<0,05)$.

Johtopäätökset. . Suomenmaatiaissiat lihovat maltillisesti, vaikka rehussa on runsaasti rasvaa ja sokeria. Kuidun vaikutuksesta lihomiseen ei voida tehdä tarkkaa johtopäätöstä, koska rehun energiapitoisuutta ei vakioitu ryhmien välillä. Lihavuuteen liittyvä krooninen matala-asteinen tulehdus johtaa siallakin granulosyyttien määrän kohoamiseen ja niiden muuttumiseen nopeasti reagoiviksi tulehdussoluiksi. Tulos varmennetaan analysoimalla vielä sytokiinit. Seerumi- ja kudosnäytteiden tutkimisen jälkeen voidaan arvioida, mitä markkereita kannattaa jatkossa tutkia. Lihavuudessa tulehdusmuutokset tapahtuvat hitaasti, mikä on otettava huomioon tutkimuksen kestossa.

\section{Asiasanat}

sika, mallieläin, ihminen, lihavuus, tulehdus, metabolinen oireyhtymä, valkosolu 


\section{Johdanto}

Lihavuus on maailmanlaajuinen ongelma, joka aiheuttaa suoraan tai välillisesti huomattavan osan ihmisten terveysongelmista ja kuolemantapauksista. Äidin lihavuuden tiedetään altistavan sikiökuolemille ja epämuodostumille. Lisäksi lihavan äidin lapsella on suurempi todennäköisyys sairastua myöhemmin elämässään lihavuuteen, sydän- ja verisuonitauteihin, 2-tyypin diabetekseen (Heiskanen ym. 2006) ja syöpään (Thornburg ym. 2010) kuin normaalipainoisen äidin lapsella.

Runsaskuituisen ruokavalion tiedetään auttavan painonhallinnassa ja vähentävän elintapasairauksien, kuten 2-tyypin diabeteksen esiintyvyyttä (Barclay ym. 2008). Liukoiset kuidut hidastavat ravintoaineiden imeytymistä ohutsuolesta verenkiertoon ja siten madaltavat elimistön glukoosi- ja insuliinipitoisuuksien huippuja ruokailun jälkeen. Ravintokuitu lisää myös kylläisyyden tunnetta. Lisäksi ravintokuitu vaikuttaa ruuansulatuskanavasta ja rasvakudoksesta peräisin olevien hormonien eritykseen (Weickert and Pfeiffer 2008). Ihmisen lihomista on mallinnettu jyrsijöiden avulla, mutta jyrsijöiden kasvu ja eräät aineenvaihdunnan ominaisuudet poikkeavat ihmisestä enemmän kuin sian vastaavat. Esimerkiksi jyrsijöiden poikasten aivot ja ruuansulatuselimistö jatkavat kehittymistään imetyskauden aikana kun taas ihmislasten aivot ja ruuansulatuselimistö ovat syntyessä jo pitkälle kehittyneitä. Porsaat puolestaan syntyvät vain hieman vähemmän kehittyneinä kuin ihmislapset (Puiman ja Stoll, 2008). Lisäksi esimerkiksi lihavuuteen liitetyn adiponektiini-hormonin toiminta eroaa jyrsijöillä ja ihmisillä: lihavilla ihmisillä ja sioilla on vähemmän verenkierrossa kuin normaalipainoisilla, mutta lihavilla rotilla adiponektiinia on enemmän verenkierrossa kuin normaalipainoisilla rotilla (Spurlock ja Gabler, 2008). Sian käyttämistä ihmisen mallieläimenä puoltaa myös kudos- ja verinäytteiden koko jyrsijöihin verrattuna, mikä mahdollistaa kudoksen ja veren tutkimisen sioilta laajemmin per yksilö kuin jyrsijöiltä. Ainakin Ossabaw-rotuinen minisika ja Large White -rotuinen lihantuotantosika on todettu hyväksi ihmismalliksi lihavuuteen liittyvien aineenvaihduntasairauksien tutkimisessa (Lee ym. 2009, Williams ym. 2009) ja sian genomin ja kromosomien rakenteen on todettu olevan hyvin samantyyppisiä kuin ihmisen (Lunney 2007).

Ihmisen keskivartalolihavuuteen liittyy krooninen matala-asteinen tulehdus, joka saa alkunsa rasvakudoksesta ja joka heijastuu koko elimistöön kohonneina tulehdusvälittäjäaineiden määrinä ja valkosolujen liika-aktiivisuutena sekä kasvaneena radikaalintuottona. Tulehdus itsessään johtaa insuliiniresistenssiin mm. kohonneen "tumor necrosis factor" (TNF) -alfan (tulehduksen välittäjäaine) välityksellä. Veren tulehdustekijät ja tulehdussoluiksi muuttuneet valkosolut ovat keskeisiä tekijöitä monien kansantautiemme kuten valtimotaudin, 2-tyypin diabeteksen syy-seuraussuhteessa ja sairauden etenemisessä (Gregor ja Hotamisligil 2011). Nämä ovat dynaamisia prosesseja, joihin voidaan selkeästi vaikuttaa ruokavaliolla (Lamb ja Goldstein 2008).

Suomessa on tuotantoeläinsikaa käytetty ihmismallina jo useassa tutkimuksessa (Kemppinen ym. 1993, Pakarinen ym. 1997, Pakarinen ym. 2004, Roivainen ym. 2001, Suomi ym. 1993 ja Fava ym. 2007). Näissä tutkimusaiheet ovat olleet: eri ravintorasvan lähteiden vaikutukset sikojen tuotantotuloksiin sekä seerumin kolesteroliin ja triglyserideihin, ohutsuolisiirroksen vaikutukset rasva-aineenvaihduntaan, kasvuhormonin vaikutukset kolesterolin imeytymiseen ohutsuolisiirroksen jälkeen, enterovirusten ja haiman beetasolujen (insuliinia tuottavien solujen) yhteyksien löytäminen ja liukoisen kuidun vaikutus sikojen suoliston mikrobeihin. Kuitenkaan ei voida olla täysin varmoja, soveltuuko suomalainen maatiaissika ihmismalliksi lihavuuteen liittyvien aineenvaihduntaparametrien tutkimuksessa. Tämä koe oli pilottikoe tutkimushankkeelle, jossa pyritään selvittämään, voiko äidin ylipainoisuus ja runsasrasvainen ruokavalio altistaa lapset lihavuudelle ja voidaanko lapsille mahdollisesti periytyvää lihomistaipumusta estää ruokavaliolla. Sioilla kasvatusajan ruokinta vaikuttaa sukukypsyysikään ja tiinehtymiseen. Ei ole tiedossa, häiritseekö runsasrasvainen ja -sokerinen kasvatusajan ruokinta sukukypsyyden ilmenemistä. Yleensä ensikoiden ruokintaa rajoitetaan kasvatusaikana, jotta niiden jalkaterveys pysyisi hyvänä myös tiineyden ja imetyksen aikana (Siljander-Rasi ym. 2006). Jotta äidin lihavuuden ja ravitsemuksen vaikutusta lasten lihavuuteen olisi mielekästä mallintaa sioilla, sikojen pitäisi lihoa rasvarehulla. Toisaalta, siat eivät saisi lihoa liikaa, jotta niiden lisääntymis- ja liikuntakyky eivät heikentyisi liiaksi.

Tässä pilottikokeessa selvitettiin: 1) syövätkö siat rasva- ja sokerirehua tarpeeksi lihoakseen (sikojen tiedetään täsmäävän syöntiään energian tarpeen mukaan), 2) mikä on rasvarehua syövien sikojen kasvunopeus verrattuna kontrolliryhmän sikoihin, 3) miten sian ihonalaisen rasvakudoksen paksuus kehittyy kasvatuksen aikana, 4) voidaanko sisäelinrasvan kertymistä seurata luotettavasti ultraäänellä elävästä eläimestä, 5) vaikuttaako rasvarehu ensimmäisen kiiman esiintymisajankohtaan, 6) saadaanko rasva- ja sokerirehulla sialle kehittymään sisäelinrasvakudoksen krooninen tulehdustila, 7) näkyykö 
tulehdustila sian veren kohonneina valkosolujen määrinä tai granulosyyttien aktiivisuuden muutoksena?

\section{Aineisto ja menetelmät}

Kokeessa kasvatettiin 43 suomenmaatiaisrodun emakkoporsasta 33-35 kg painosta noin $140 \mathrm{~kg}$ painoon. Siat kasvatettiin ja ruokittiin yksilökarsinoissa.

Siat jaettiin neljään ruokintakäsittelyyn siten, että sisaret ja puolisisaret arvottiin eri käsittelyihin. Sikojen ruokinta oli kaksivaiheinen: Kontrollikäsittelyssä 1 alkukasvatus kesti 5 viikkoa ja loppukasvatus siitä teurastukseen saakka. Siat saivat ensikoiden kasvatukseen tarkoitettuja alku- ja loppukasvatusrehuja, joita annettiin nopean kasvatuksen energiaruokintasuosituksen mukaan (MTT, 2009). Koekäsittelyissä 2-4 kontrollirehu vaihdettiin ensimmäisten 7 kasvatusviikon aikana asteittain energiapitoiseen lihotusrehuun, minkä lisäksi siat saivat rasvaa ja sokeria (Taulukko 1). Rasvalisästä $50 \%$ oli voita ja $50 \%$ margariinirasvaa. Ryhmien 2-4 ensikot saivat saman määrän rehukiloja päivässä kuin kontrolliryhmän ensikot, tavanomainen rehu vain korvattiin lihotusrehulla rasva- ja sokerilisineen.

Taulukko 1. Koeryhmät ja ruokinnat.

\begin{tabular}{|c|c|c|c|c|}
\hline Ryhmä & 1 & 2 & 3 & 4 \\
\hline Sikojen lukumäärä & 10 & 11 & 10 & 11 \\
\hline \multirow[t]{3}{*}{ Alkukasvatus } & tavanomainen & totutus 7 viikon & totutus 7 viikon & totutus 7 viikon \\
\hline & 5 viikkoa & aikana seokselle & aikana seokselle & aikana seokselle \\
\hline & & A+rasva+sokeri & A+rasva+sokeri & $\mathrm{B}+$ rasva+sokeri \\
\hline Loppukasvatus & $\begin{array}{l}\text { tavanomainen } \\
\text { teurastukseen asti }\end{array}$ & Seos A & Seos A & Seos B \\
\hline $\begin{array}{l}\text { Lisätty rasva rehussa, } \\
\text { paino-\% }\end{array}$ & - & 8,4 & 14,6 & 13,9 \\
\hline $\begin{array}{l}\text { Lisätty sokeri rehussa, paino- } \\
\%\end{array}$ & - & 15 & 15 & 10 \\
\hline \multicolumn{5}{|l|}{$\begin{array}{l}\text { Laskennallisesti } \\
\text { energiasta kasvatuksen lopussa } \\
\%\end{array}$} \\
\hline -proteiineista $17 \mathrm{~kJ} / \mathrm{g}$ & 19,1 & 16,2 & 14,5 & 16,7 \\
\hline -rasvasta $37 \mathrm{~kJ} / \mathrm{g}$ & 10,7 & 20,2 & 28,5 & 30,6 \\
\hline $\begin{array}{l}\text {-imeytyvistä } \\
\text { hiilihydraateista } 17 \mathrm{~kJ} / \mathrm{g}\end{array}$ & 70,2 & 63,7 & 57,0 & 52,6 \\
\hline
\end{tabular}

Siat punnittiin kokeen alussa, loppukasvatuksen alkaessa ( $5 \mathrm{vk}$ ), tilatestauksen yhteydessä (noin 100 kg paino) ja kokeen lopussa. Punnituksen yhteydessä sioilta mitattiin ultraäänellä vatsan rasvakerroksen paksuus navan etupuolelta ja selkäsilavan paksuus viimeisen kylkiluun puolivälin kohdalta selän molemmin puolin. Selkäsilavan paksuudesta pyrittiin ennustamaan sian kokonaisrasvapitoisuutta matemaattisella kaavalla (Madsen ym. 2008). Samoina ajankohtina sioilta mitattiin myös vyötärönympärysmitta välittömästi kylkiluiden takaa, säkäkorkeus, sian pituus väliltä säkä-saparontyvi ja sian leveys takaa päin kinkkujen leveimmältä kohdalta sekä otettiin paastoverinäytteet EDTA- ja seroputkiin.

Seroputket sentrifugoitiin ja seeruminäytteet pakastettiin myöhempiä sytokiinimittauksia varten. EDTA-verestä mitattiin 6h kuluessa fagosytoivien valkosolujen (granulosyytit ja monosyytit) happiradikaalien tuotto kineettisesti ajan funktiona ("respiratory burst"-aktiivisuus) käyttäen metodia, joka on kehitetty rotille (Lojek ym. 1997) ja joka modifioitiin sian näytteille sopivaksi. Valkosoluja stimuloitiin sian seerumissa opsonisoidulla zymosaanilla ja happiradikaalien tuottoa mitattiin kineettisesti luminolilla vahvistettuna valontuottona (CL-reaktio). EDTA-verinäytteistä laskettiin mikroskoopilla valkosolujen kokonaismäärät käyttäen metyyliviolettia ja Bürkerin kammiota. Punasolut hajotettiin hypotonisella liuoksella, jonka jälkeen valkosolut pestiin ja granulosyyttien, monosyyttien ja lymfosyyttien suhteelliset osuudet mitattiin virtaussytometrilla.

Siat teurastettiin HK Ruokatalo Oy:n teurastamossa Mellilässä ja niistä kerättiin teurastiedot ja otettiin punnittavaksi vatsaontelon sisäinen rasva. Tuotantotulokset analysoitiin SAS-ohjelmistolla käyttäen MIXED-mallia, jossa ryhmä oli kiinteä tekijä ja koesikojen isä satunnainen tekijä. Parametrit, joista on useampi mittaus kasvun aikana, analysoitiin toistomittauksina. 


\section{Tulokset ja tulosten tarkastelu}

Sikojen päiväkasvu kaikissa ryhmissä oli hyvä koko kokeen ajan ja niiden 1. kiima havaittiin viittä sikaa lukuun ottamatta keskimäärin 149-159 päivän iässä. Tilastollisesti merkitseviä eroja ryhmien välille ei tullut. Sikojen teuraspaino ylitti $100 \mathrm{~kg}$ ja rasvaryhmien (2-4) siat näyttivät teurastamon silavamittojen perusteella rasvoittuneen kontrolliryhmän sikoja enemmän, mutta ero ei ollut tilastollisesti merkitsevä (Taulukko 2).

Taulukko 2. Ensikoiden päiväkasvu ja teurastulokset (keskiarvo \pm keskiarvon keskivirhe)

\begin{tabular}{lllll}
\hline Ryhmä & 1 & 2 & 3 & 4 \\
\hline Alkupaino, kg & $35,0 \pm 1,3$ & $34,5 \pm 1,3$ & $34,2 \pm 1,3$ & $33,0 \pm 1,3$ \\
Loppupaino, kg & $141,6 \pm 3,3$ & $140,3 \pm 3,3$ & $138,6 \pm 3,4$ & $141,7 \pm 3,3$ \\
Kasvu koko kokeen aikana & $1009 \pm 22$ & $996 \pm 22$ & $975 \pm 23$ & $992 \pm 22$ \\
g/pv & & & \\
Kiimaantuloikä, d & $152 \pm 4,1$ & $159 \pm 4,2$ & $149 \pm 4,2$ & $157 \pm 3,8$ \\
Teuraspaino, kg & $105,2 \pm 0,63$ & $106,0 \pm 0,61$ & $105,5 \pm 0,65$ & $106,6 \pm 0,61$ \\
Lihaprosentti & $58,1 \pm 0,93$ & $56,0 \pm 0,91$ & $55,6 \pm 0,95$ & $57,1 \pm 0,91$ \\
Teurastappio, \% & $25,1 \pm 0,44$ & $24,6 \pm 0,43$ & $25,0 \pm 0,45$ & $24,1 \pm 0,43$ \\
Lihasmitta, mm & $59 \pm 1,4$ & $59 \pm 1,3$ & $55 \pm 1,5$ & $60 \pm 1,4$ \\
Sisäelinrasva, kg & $1,36 \pm 0,12$ & $1,82 \pm 0,10$ & $1,54 \pm 0,11$ & $1,53 \pm 0,11$ \\
S1 & $15,8 \pm 1,2$ & $18,1 \pm 1,2$ & $18,2 \pm 1,3$ & $16,5 \pm 1,2$ \\
S2 & $14,9 \pm 1,0$ & $17,2 \pm 0,9$ & $17,8 \pm 1,0$ & $15,9 \pm 1,0$ \\
\hline
\end{tabular}

ryhmät: 1=kontrolli, 2=lisärasva $8,4 \%+$ sokeri $15 \%, 3=$ lisärasva $14,6 \%+$ sokeri $15 \%$, 4=lisärasva $13,9 \%+$ sokeri $10 \%+$ lese

Vaikka rasvaryhmien (2-4) siat saivat rehussaan enemmän energiaa (Kuva 1.) kuin kontrolliryhmän siat, kasvatuksen aikana ultraäänellä mitattu selkäsilavan paksuus näytti kehittyvän rasvaryhmissä vain hieman nopeammin $(\mathrm{p}<0,1)$ kuin kontrolliryhmässä, mutta erot olivat pieniä. Mahasilavan paksuus kehittyi ryhmissä vielä yhdenmukaisemmin kuin selkäsilavan paksuus (Kuva 2). Ryhmien väliset pienet erot saattoivat johtua siitä, että energian lisäksi rasvaryhmät saivat rehussaan kohtuullisen runsaasti valkuaista, mikä piti yllä punaisen lihan kasvua, päiväkasvukaan ei hidastunut rasvaryhmissä dramaattisesti. Sianruhon kokonaisrasvapitoisuuden kehityksen ennustaminen matemaattisella kaavalla selkä- ja mahasilavatulosten perusteella ei tässä kokeessa esitetyllä tavalla ole mielekästä, tulosten korrelaatio oli heikko.

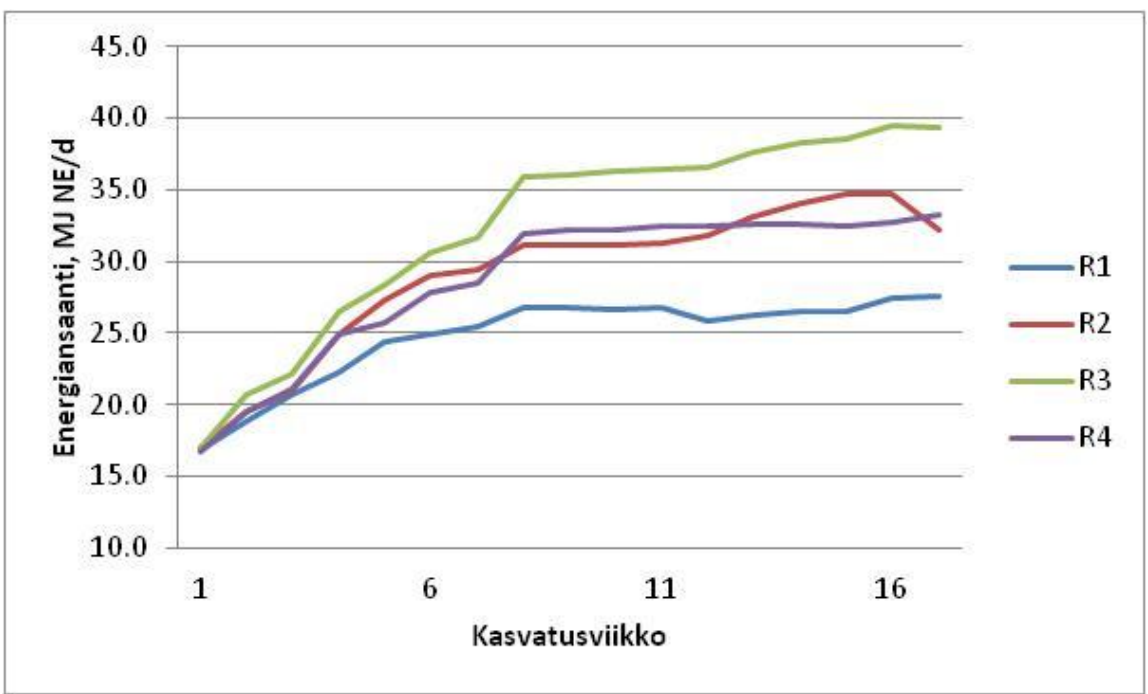

Kuva 1. Ensikoiden laskennallinen energiansaanti kokeen aikana 


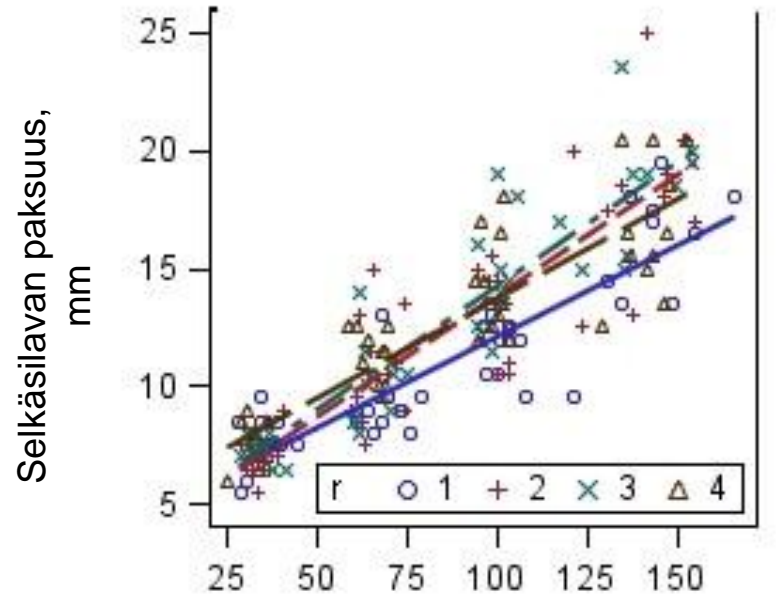

Elopaino, $\mathrm{kg}$

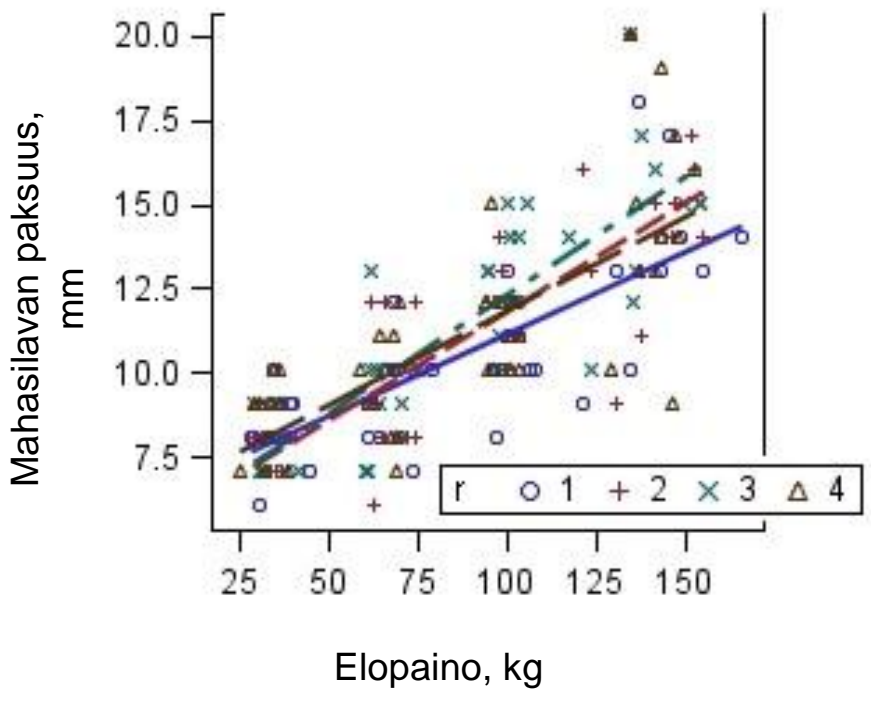

Kuva 2. Ensikoiden selkä- ja mahasilavan paksuuden kehitys kokeen aikana. Ryhmät: 1=kontrolli, 2=lisärasva 8,4 \%+ sokeri $15 \%, 3=$ lisärasva $14,6 \%+$ sokeri $15 \%$, 4=lisärasva $13,9 \%+$ sokeri $10 \%+$ lese

Kolmessa ensimmäisessä verinäytteiden ottoajankohdassa (alku, $5 \mathrm{vk}$ ja noin $100 \mathrm{~kg}$ paino) laskimoveren valkosolujen määrissä tai valkosolujen aktiivisuuksissa ei ollut merkitseviä eroja ryhmien välillä (dataa ei esitetä). Vasta kokeen loppuvaiheessa 135-140 kg elopainossa otetuissa neljänsissä verinäytteissä oli nähtävissä tilastollisesti merkitseviä tulehdusmuutoksia (Taulukko 3). Granulosyyttien määrä kontrolliryhmään verrattuna erosi vain ryhmässä 4 , joka oli toiseksi eniten rasvaa saanut ryhmä. Granulosyyttien happiradikaalien tuoton ("respiratory burst"-aktiivisuus) kinetiikassa tulehdukseen viittaava muutos havaittiin kahdessa eniten rasvaa syöneessä ryhmässä (ryhmät 3 ja 4). Reaktiohuipun korkeudessa eroa ei ollut ryhmien välillä. Tekemissämme esikokeissa muutimme in vitro terveen sian granulosyytit kolibakteerin lipopolysakkaridin (LPS) sekä ihmisen TNF-alfan avulla tulehdussoluiksi. Käsittelyt saivat aikaan CL-reaktion (valontuotto) nopeutumisen, kuten tapahtuu ihmisen ja rotan soluillakin. LPSkäsittelyssä myös CL-reaktiohuippu nousee, mutta TNF-alfalla käsiteltäessä se ainoastaan nopeutuu.

Taulukko 3. Kokeen lopussa otettujen laskimoverinäytteiden valkosolumäärät ja granulosyyttien happiradikaalien tuotanto ("respiratory burst"-aktiivisuus) CL-reaktiona (rlu = relative light unit). Luvut ovat k.a. \pm S.D.

Tilastolliset merkitsevyydet on esitetty kontrolliryhmään (ryhmä 1) verrattuna ja perustuvat joko yksisuuntaiseen varianssianalyysiin (kontrastit Holm-Sidak-menet.) tai Kruskall-Wallisin yksisuuntaiseen varianssianalyysiin.

\begin{tabular}{lcccc}
\hline Ruokintaryhmä & 1 & 2 & 3 & 4 \\
\hline Sikojen lukumäärä & 10 & 11 & 11 & 11 \\
Kok. leukosyytit $10^{6} / \mathrm{ml}$ & $16,34 \pm 2,50$ & $17,24 \pm 3,66$ & $16,93 \pm 3,13$ & $20,36 \pm 4,95^{\circ}$ \\
Granulosyytit $10^{6} / \mathrm{ml}$ & $5,34 \pm 1,67$ & $5,63 \pm 2,32$ & $4,73 \pm 1,26$ & $7,01 \pm 1,72^{*}$ \\
Monosyytit $10^{6} / \mathrm{ml}$ & $0,890 \pm 0,154$ & $1,007 \pm 0,341$ & $0,950 \pm 0,249$ & $1,043 \pm 0,379$ \\
Lymfosyytit $10^{6} / \mathrm{ml}$ & $10,11 \pm 2,78$ & $10,60 \pm 2,24$ & $11,25 \pm 2,34$ & $12,32 \pm 3,31$ \\
$\begin{array}{l}\text { CL-reaktiohuippu (rlu) per 40nl } \\
\text { verta }\end{array}$ & $399 \pm 119$ & $420 \pm 162$ & $403 \pm 106$ & $396 \pm 145$ \\
$\begin{array}{l}\text { CL-reaktionopeus } \\
\text { huipun aika sekunteina }\end{array}$ & $1113 \pm 124$ & $1025 \pm 165$ & $966 \pm 112^{*}$ & $933 \pm 138^{*}$ \\
\hline
\end{tabular}

Ihmisillä keskivartalolihavuuden seurauksena syntyvä krooninen matala-asteinen tulehdus kehittyy hitaasti (Gregor ja Hotamisligil 2011). Näin on todennäköisesti myös sialla, joten merkittäviä lihavuuteen liittyviä tulehdusmuutoksia ei voitane odottaakaan ilmaantuvan aikaisessa vaiheessa koetta. Tämä asettaa jatkossa vaatimuksia sioilla tehtävien tutkimusten kestolle.

Paljon tyydyttynyttä rasvaa sisältävän ruokavalion tiedetään muuttavan ihmisellä normaalitilaiset granulosyytit tulehdussoluiksi, joiden CL-reaktionopeus on suurempi kuin normaalitilassa (Condliffe ym.1998). Tyypin 2 diabetestä sairastavilla ihmisillä laskimoveren granulosyyttien CL-reaktio on nopeampi ja voimakkaampi kuin terveillä (Prilutsky ym. 2008). CL-vaste heijastaa hyvin ihmisen tulehdustilaa (Lilius 
\& Marnila 1992). Ihmisillä koholla oleva valkosolumäärä laskimoveressä liittyy metaboliseen oireyhtymään (Chen ym. 2010) ja ennustaa kohonnutta riskiä kuolla valtimotautiin.

Vaikka Taulukon 3 tulokset sopivatkin loogisesti hyvin siihen, mitä tiedetään ihmisen lihavuuteen liittyvästä kroonisesta tulehduksesta, tämän pilottikokeen koeryhmät olivat pienet ja merkitseviä eroja oli ainoastaan viimeisessä aikapisteessä. Siksi myös sytokiineja on vielä analysoitava kerätyistä seeruminäytteistä ja niiden pitoisuuksia on verrattava yksilökohtaisesti valkosolutuloksiin sekä rasvakudosnäytteiden tietoihin. Nämä lisätiedot tarvitaan, jotta tiedetään, liittyvätkö havaitut muutokset valkosolujen määrissä ja toiminnassa ruokinnan ja lihavuuden aiheuttamaan krooniseen tulehdukseen.

\section{Johtopäätökset}

Ensikot lihovat jonkin verran rasvalla ja sokerilla höystetyllä rehulla. Vaikka rehun energiasta tulee poikkeavan suuri osa rasvasta ja sokerista, ensikot kasvavat hyvin ja ne pystyvät kasvattamaan lihasmassaa, kun rehussa on runsaasti valkuaista. Rehun rasva- ja sokeripitoisuudella ei ole vaikutusta ensikoiden kiimaan tuloikään.

Runsasrasvaiseen ruokavalioon ja lihavuuteen liittyvä krooninen matala-asteinen tulehdus voidaan todennäköisesti mitata sialta valkosolujen kohonneina määrinä ja nopeutuneena CL-reaktionopeutena. Tämä pitää kuitenkin vielä varmentaa analysoimalla seerumien sytokiinit. Merkittäviä lihavuuteen liittyviä tulehdusmuutoksia ei siallakaan tapahdu nopeasti, mikä asettaa jatkossa vaatimuksia tutkimuksen kestolle.

\section{Kirjallisuus}

Barclay, A. W., Petocz, P. McMillan-Price, J., Flood, V. M., Prvan, T., Mitchell, P. \& Brand-Miller, J. C. 2008. Glycemic index, glycemic load, and chronic disease risk - a meta-analysis of observational studies. American Journal of Clinical Nutrition 87: 627-637.

Chen, W., Srinivasan, S.R., Xu, J. \& Berenson, G.S. 2010. Black-white divergence in the relation of white blood cell count to metabolic syndrome in preadolescents, adolescents, and young adults: the Bogalusa Heart Study. Diabetes Care 33(11):2474-2476.

Condliffe, A.M., Kitchen, E. \& Chilvers, E.R. 1998. Neutrophil priming: pathophysiological consequences and underlying mechanisms. Clinical Science (Lond) 94(5):461-471.

Fava, F., Mäkivuokko, H., Siljander-Rasi, H., Putaala, H., Tiihonen, K., Stowell, J., Tuohy, K., Gibson, G. \& Rautonen, N. 2007. Effect of polydextrose on intestinal microbes and immune functions in pigs. British Journal of Nutrition 98: 123-133.

Gregor, M.F. \& Hotamisligil, G.S. 2011. Inflammatory mechanisms in obesity. Annual Review of Immunology 29: 415-445.

Heiskanen, N., Raatikainen, K. \& Heinonen, S. 2006. Fetal macrosomia - a continuing obstetric challenge. Biology of the Neonate 90: 98-103.

Kemppinen, A., Jauhiainen, M., Kankare, V., Valaja, J., Alaviuhkola, T., Aro, A. \& Antila, P. 1993. Effects of milk fat, unhydrogenated and partially hydrogenated vegetable oils on fat metabolism of growing pigs : II.Changes in serum cholesterol and triglyceride levels. Agricultural Science in Finland 2: 15-22.

Lamb, R.E., Goldstein, B.J. 2008. Modulating an oxidative-inflammatory cascade: potential new treatment strategy for improving glucose metabolism, insulin resistance, and vascular function. International Journal Clinical Practise 62(7): 1087-1095.

Lee, L., Alloosh, M., Saxena, R., Van Alstine, W., Watkins, B. A., Klaunig, J. E., Sturek, M. \& Chalasani, N. 2009. Nutritional model of steatohepatitis and metabolic syndrome in the ossabaw miniature swine. Hepatology 50: 56-67.

Lilius, E-M. \& Marnila, P. 1992. Photon emission of phagocytes in relation to stress and disease. Review article. Experientia 48, (11-12): 1082-1091.

Lojek, A., Ciz, M., Marnila, P., Duskova, M. \& Lilius, E-M. 1997. Measurement of whole blood phagocyte chemiluminescence in the Wistar rat. Journal of Bioluminescence and Chemiluminescence 12: 225-231.

Lunney, J. K. 2007. Advances in swine biomedical model genomics. International Journal of Biological Sciences 3:179-184.

Madsen, M. T., McEvoy, F., Nielsen, M. B. F. \& Svalastoga, E. 2008. Sammenhaeng mellem spaektykkelse og poltes inhold af fedt. Meddelelse nr. 814. Dansk Svineproduktion. http://vsp.lf.dk/Publikationer/Kilder/lu_medd/2008/814.aspx viitattu 23.11.2011.

Pakarinen, M., Miettinen, T. A., Kuusanmäki, P. Vento, P., Kivistö, T. \& Halttunen, J. 1997. Effect of ileal autotransplantation on cholesterol, bile acids, and biliary lipids in pigs with proximal small bowel resection. Hepatology 25: 1315-1322.

Pakarinen, M. P., Pirinen, P., Lauronen, J., Raivio, P., Kuusanmäki, P. \& Halttunen, J. 2004. Growth hormone 
selectively improves intestinal cholesterol absorption after jejunoileal autotransplantation in pigs. Journal of Pediatric Surgery 39: 1220-1225.

Prilutsky, D., Rogachev, B., Vorobiov, M., Zlotnik, M., Last, M., Lobel, L. \& Marks, R.S. 2008. Dynamic component chemiluminescent sensor for assessing circulating polymorphonuclear leukocyte activity of peritoneal dialysis patients. Analytical Chemistry 80(13):5131-5138.

Puiman, P. \& Stoll, B. 2008. Animal models to study neonatal nutrition in humans. Current Opinion in Clinical Nutrition and Metabolic Care 11:601-606

Roivainen, M., Ylipaasto, P., Ustinov, J., Hovi, T. \& Otonkoski, T. 2001. Screening enteroviruses for $\beta$-cell tropism using foetal porcine $\beta$-cells. Journal of General Virology 82:1909-1916.

Siljander-Rasi, H., Nopanen, A. \& Helin, J. 2006. Sian ruokinta ja hoito. Tieto Tuottamaan 114. ProAgria Maaseutukeskusten liiton julkaisuja nro 1024. Gummerus Kirjapaino Oy, Jyväskylä ISSN 0357-7295.

Spurlock, M. E. \& Gabler, N. K. 2008. The Development of porcine models of obesity and the metabolic syndrome. The Journal of Nutrition 138: 397-402.

Suomi, K., Alaviuhkola, T., Valaja, J., Kankare, V. \& Kemppinen, A. 1993. Effects of milk fat, unhydrogenated and partially hydrogenated vegetable oils on fat metabolism of growing pigs: I.Growth, feed utilization and carcass quality in pigs fed different fats and oils. Agricultural Science in Finland 2: 7-13.

Thornburg, K. L., Shannon, J., Thuillier, P. \& Turker M. S. 2010. 3 - in utero life and epigenetic predisposition for disease. Advances in Genetics 71: 57-78.

Williams, P. J., Marten, N., Wilson, V., Litten-Brown, J. C., Corson, A. M., Clarke, L., Symonds, M. E. \& Mostyn, A. 2009. Influence of birth weight on gene regulators of lipid metabolism and utilization in subcutaneous adipose tissue and skeletal muscle of neonatal pigs. Reproduction 138: 609-617. 